- Outlines which oral symptoms and signs require urgent referral to secondary care.

- Referral letters should include relevant contact details and the words 'cancer' or

\title{
An audit of the UK national cancer referral guidelines for suspected oral mucosal malignancy
}

\author{
T. A. Hodgson, ${ }^{1}$ J. A. G. Buchanan, ${ }^{2}$ A. Garg, ${ }^{3}$ S. E. Ilyas ${ }^{4}$ and S. R. Porter ${ }^{5}$
}

Background and objective This study aimed to assess the effectiveness of the UK National Guidelines for identifying patients with potentially malignant oral disease which were introduced in 2000. Design Retrospective audit. Setting The oral medicine unit in a university teaching hospital in London. Methods All new referrals over a one year period were retrospectively reviewed in a departmental audit to evaluate guideline effectiveness. Reasons for referral and final diagnosis were compared in a randomly selected sub-population. Results Four hundred and eighty-seven of 901 new patients referred were classified as having potentially malignant disease from the referral letter. In a randomly selected subgroup of 241 patients, 18 actually had malignant (8) or dysplastic lesions (10). Of 75 patients referred with a persistent oral ulcer, only nine were actually malignant or dysplastic. Eight of 116 patients referred with a white patch and none with red patches were found to have dysplastic or malignant lesions. The criteria failed to identify three carcinomas and two severely dysplastic lesions (15\% of the malignant or dysplastic lesions). All of the latter had been referred by primary care physicians with orofacial pain of unknown cause. Conclusions UK National Guidelines discriminate poorly between potentially malignant and other oral mucosal disease.

\section{INTRODUCTION}

Early detection of suspicious oral lesions in primary care with timely, appropriate referral by the general dental practitioner (GDP) or general medical practitioner (GMP) to a specialist centre expedites early diagnosis, assessment and subsequent management of oral malignancies. $^{2-4}$

The United Kingdom (UK) Government White Paper entitled The new

\footnotetext{
${ }^{1 *}$ Consultant/Honorary Lecturer, ${ }^{2}$ Locum Consultant/Honorary Lecturer, ${ }^{3}$ Postgraduate Student, ${ }^{4}$ Senior House Officer, ${ }^{5}$ Professor/Honorary Consultant, Unit of Oral Medicine, Division of Maxillofacial Medical Diagnostic and Surgical Sciences, Eastman Dental Hospital, UCLH NHS Foundation Trust and UCL Eastman Dental Institute, 256 Gray's Inn Road, London, WC1X 8LD ${ }^{*}$ Correspondence to: Dr Tim Hodgson Email: t.hodgson@eastman.ucl.ac.uk
}

National Health Service (NHS) - modern, dependable guaranteed that every person with suspected cancer would be seen by a specialist within two weeks of their GMP requesting an appointment. ${ }^{5}$ In order to facilitate appropriate referral between primary and secondary care for a patient with a probable cancer diagnosis, guidelines, including those for head and neck malignancies with relevance to oral malignancy, were introduced along with a two-week wait standard for oral malignancy from December 2000. ${ }^{1}$ Unfortunately since the target group for this was GMPs, many GDPs may have been unaware of this. The clinical features of oral lesions deemed suggestive of malignant change in the National Guidelines are listed in Table 1.

To date, there has been no published detailed analysis of the effectiveness of these guidelines in an oral medicine unit. The aim of the present audit was to determine the effectiveness of the UK National Guidelines in identifying patients with malignant and dysplastic oral mucosal disease from referral letters.

Table 1 Head and neck cancer: guidelines for urgent referral of suspected cancer as defined by the UK National Guidelines ${ }^{1}$

All red or red and white patches of the oral mucosa*

Ulceration of the oral mucosa $>3$ weeks*

Unresolving neck masses for $>3$ weeks

Unexplained tooth mobility not associated with periodontal disease

Cranial neuropathies

Dysphagia for 3 weeks

Hoarseness $>6$ weeks

Orbital masses

Unilateral nasal obstruction associated with purulent discharge

*Lesions most commonly referred to the Eastman oral medicine clinic 


\section{METHOD}

The referral letters of all new patients accepted by the Unit of Oral Medicine, Eastman Dental Institute for Oral Health Care Sciences, London, United Kingdom for one year were reviewed in a departmental audit and the name, age, referral source, health authority and clinical diagnosis recorded for each patient. All referral diagnoses of orofacial lesions classified as potentially malignant, as defined by the recently published national guidelines (Table 1), were identified. ${ }^{1}$ Fifty percent of this subgroup was then randomly selected by computer. The hospital notes of the subgroup were reviewed and details of tobacco use, alcohol consumption and final diagnosis entered on to an Excel spreadsheet.

The relationship between risk factors and the presence of dysplasia and malignancy was analysed using Fisher's exact test.

\section{RESULTS}

One thousand, one hundred and fortyeight new referrals were received by the Oral Medicine unit over a 12 month period. Of these 901 were accepted as suitable for assessment. Two hundred and forty-seven were deemed inappropriate and redirected to other dental or medical specialities. The median age of accepted new referrals was 46 years (range 3-96 years). The majority of referrals were from GDPs (71\%), while 8\% were from GMPs, $11 \%$ from tertiary dental and 9\% from tertiary medical specialities.

Fifty-four percent of the total number of accepted patients (487 patients) had been referred with potentially malignant lesions as defined by the content of their referral letters using the guideline criteria (Fig. 1). From this group 241 patients were randomly selected for further study. The median age of this subgroup was 56 years (range 12-86 years) and consisted of a 1:1.1 ratio of males to females.

Dysplasia or malignant disease was confirmed in 18 of the 241 patients (7.4\%) referred with potential malignancy in this sample and included seven squamous cell carcinomas, one Kaposi's sarcoma and 10 dysplastic lesions (Table 2). Of the 116 patients referred with a white patch affecting the oral mucosa, five $(4.3 \%)$ were found to be dysplastic and three malignant (2.6\%) (Table 2).
Table 2 Referring and actual diagnoses of 241 patients with potentially malignant disease

\begin{tabular}{|c|c|c|c|c|c|}
\hline $\begin{array}{l}\text { Referring } \\
\text { diagnosis }\end{array}$ & $\begin{array}{l}\text { Number of } \\
\text { patients }\end{array}$ & $\begin{array}{l}\text { Median } \\
\text { age }\end{array}$ & $\begin{array}{l}\text { Male: } \\
\text { female } \\
\text { ratio }\end{array}$ & Final diagnosis & $\begin{array}{l}\text { Number } \\
\text { of } \\
\text { patients }\end{array}$ \\
\hline White patch & 116 & 60 & $54: 62$ & $\begin{array}{l}\text { Lichen planus } \\
\text { Hyperkeratosis } \\
\text { Smoker's keratosis } \\
\text { Dysplasia } \\
\text { Squamous cell carcinoma } \\
\text { Recurrent aphthous stomatitis }\end{array}$ & $\begin{array}{l}60 \\
35 \\
12 \\
5 \\
3 \\
1\end{array}$ \\
\hline Red patch & 19 & 52 & $10: 9$ & $\begin{array}{l}\text { Erythema migrans } \\
\text { Erythematous candidosis } \\
\text { Smoker's keratosis } \\
\text { Hyperkeratosis }\end{array}$ & $\begin{array}{l}7 \\
10 \\
1 \\
1\end{array}$ \\
\hline $\begin{array}{l}\text { Persistent } \\
\text { ulceration }\end{array}$ & 75 & 49 & $41: 34$ & $\begin{array}{l}\text { Lichen planus } \\
\text { Chronic non specific ulceration } \\
\text { Dysplasia } \\
\text { Recurrent aphthous stomatitis } \\
\text { Kaposi's sarcoma } \\
\text { Squamous cell carcinoma }\end{array}$ & $\begin{array}{l}11 \\
39 \\
5 \\
16 \\
1 \\
3\end{array}$ \\
\hline $\begin{array}{l}\text { Intraoral mass } \\
\text { plus ulceration }\end{array}$ & 14 & 62 & $7: 7$ & $\begin{array}{l}\text { Bony exostosis } \\
\text { Trauma } \\
\text { Orofacial granulomatosis }\end{array}$ & $\begin{array}{l}5 \\
5 \\
4\end{array}$ \\
\hline $\begin{array}{l}\text { Cervical } \\
\text { Iymphadenopathy }\end{array}$ & 3 & 43 & $1: 2$ & $\begin{array}{l}\text { Hyperplastic lingual tonsils } \\
\text { Squamous cell carcinoma }\end{array}$ & $\begin{array}{l}2 \\
1\end{array}$ \\
\hline Dysphagia & 13 & 62 & $2: 11$ & $\begin{array}{l}\text { Oral dysaesthesia } \\
\text { Recurrent aphthous stomatitis } \\
\text { Erythema migrans } \\
\text { Atypical facial pain }\end{array}$ & $\begin{array}{l}5 \\
3 \\
1 \\
4\end{array}$ \\
\hline $\begin{array}{l}\text { Hoarseness } \\
\text { of voice }\end{array}$ & 1 & 45 & 1 male & Oral dysaesthesia & 1 \\
\hline
\end{tabular}

Persistent ulceration was the referring diagnosis in 75 patients of which four were malignant (5.3\%) and five dysplastic lesions (6.7\%). Cervical lymphadenopathy was the presenting sign of one of the patients ultimately found to have a squamous cell carcinoma.
None of the patients referred with red patches, intra- or extra-oral swellings, dysphagia or hoarseness were found to have oral mucosal dysplasia or malignancy (Table 2).

The UK guideline criteria failed to identify three carcinomas and two

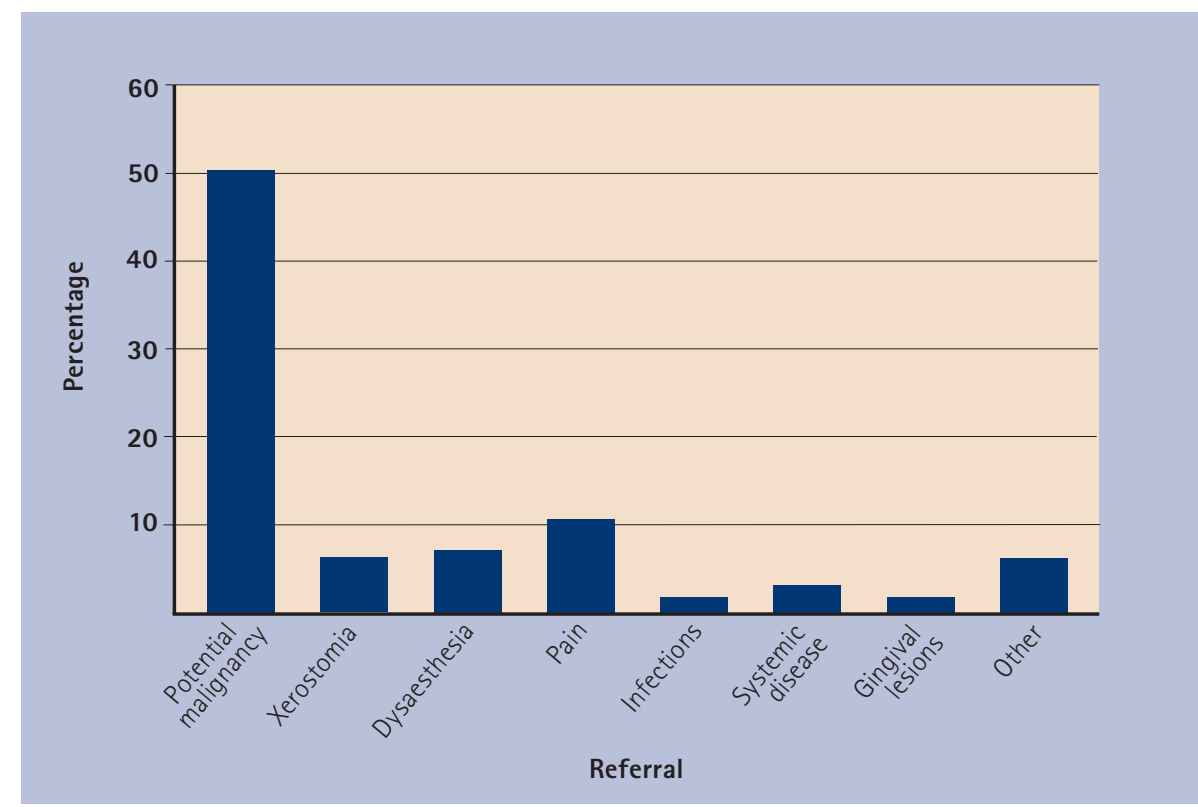

Fig. 1 Diagnosis suggested after initial reading of the referral 
severely dysplastic lesions from details included in the referral letter ie 15\% of the malignant and dysplastic lesions presenting over the 12 month period. The five referral letters concerned all contained references to facial pain with no description of the type of lesion present. In all five cases other information within the referral letters prompted the triaging clinician to arrange urgent review and these patients were all clinically examined within four weeks of the letters reaching the department.

The median age of patients with oral mucosal dysplasia was 48 years (range 33-62 years) and the ratio of males to females was 7:3 (Table 3). Half of these patients were referred as a consequence of having a white patch while the remainder were described as having persistent ulceration. The lingual mucosa was the most common site of dysplastic change, with six of 10 lesions on the lateral border and one on the dorsum of the tongue. Of the four severely dysplastic lesions three were in female patients (average age 42 years). Sixty per cent of the patients with dysplasia were non-smokers, however this was not statistically significant at the 5\% level ( $p=0.051$, Fisher's exact test) when compared to the patients without dysplasia. However, there were significantly more patients with dysplastic lesions who did not drink any alcohol ( $p=0.004$, Fisher's exact test) than those who did. In patients with severe dysplasia three of four drank alcohol and smoked tobacco (Table 4).

The median age of patients with oral malignancy was 50 years (range 39-72 years) and the ratio of males to females was 5:3 (Table 5). Four of these patients were referred as a consequence of having persistent ulceration, three had white patches and one had cervical lymphadenopathy. The lateral border and ventral surface of the tongue were the most common sites of malignancy.

With regards to risk factors, $62.5 \%$ of the patients with malignancy smoked tobacco, while $87.5 \%$ drank alcohol (Table 5). The individual found to have Kaposi's sarcoma was known to have human immunodeficiency virus infection. However, there was no significant association between the presence of malignant disease with a history of either cigarette smoking ( $p=0.27$, Fisher's exact test) or alcohol intake ( $p=0.399$, Fisher's exact
Table 3 Characteristics of 10 subjects with final diagnosis of dysplasia

\begin{tabular}{|c|c|c|c|c|c|}
\hline $\begin{array}{l}\text { Age/ } \\
\text { gender }\end{array}$ & Referring diagnosis & Site of lesion & $\begin{array}{l}\text { Degree of } \\
\text { dysplasia }\end{array}$ & $\begin{array}{l}\text { Tobacco } \\
\text { cigarettes/ } \\
\text { day }\end{array}$ & $\begin{array}{l}\text { Alcohol } \\
\text { units/ } \\
\text { week }\end{array}$ \\
\hline $48 /$ male & White patch & $\begin{array}{l}\text { Left lateral border } \\
\text { of tongue }\end{array}$ & Mild & $>20$ & $>21$ \\
\hline $53 /$ male & White patch & $\begin{array}{l}\text { Right lateral border } \\
\text { of tongue }\end{array}$ & Mild & Nil & Nil \\
\hline $37 /$ female & White patch & $\begin{array}{l}\text { Left lateral border } \\
\text { of tongue }\end{array}$ & Severe & 20 & $<14$ \\
\hline 38/female & White patch & Left buccal mucosa & Severe & Nil & Nil \\
\hline 49/male & White patch & $\begin{array}{l}\text { Junction of hard and } \\
\text { soft palate }\end{array}$ & Mild & Nil & Nil \\
\hline 33/female & Persistent ulceration & $\begin{array}{l}\text { Right lateral border } \\
\text { of tongue }\end{array}$ & Severe & $<20$ & $>14$ \\
\hline $59 /$ male & Persistent ulceration & $\begin{array}{l}\text { Left lateral border } \\
\text { of tongue }\end{array}$ & Severe & $<20$ & $<21$ \\
\hline $57 /$ male & Persistent ulceration & Dorsum of tongue & Mild & Nil & Nil \\
\hline $47 /$ male & Persistent ulceration & Floor of mouth & Mild & $\mathrm{Nil}$ & Nil \\
\hline $62 /$ male & Persistent ulceration & $\begin{array}{l}\text { Left lateral border of } \\
\text { tongue }\end{array}$ & Mild & $\mathrm{Nil}$ & Nil \\
\hline
\end{tabular}

test) (Tables 3 and 5). Of the 241 patients with supposed potentially malignant disease 65\% smoked cigarettes - much higher than the $27 \%$ found in the general population of the United Kingdom. ${ }^{6}$

\section{DISCUSSION}

To our knowledge this is the first reported audit study to review the impact of the Referral guidelines for suspected cancer on potential oral malignancy referrals to an oral medicine department. Our findings concur with those of a recent study of 100 sequential new referrals to an oral and maxillofacial surgery clinic in South-West England. ${ }^{7}$ During the year reviewed, 487 (54\%) of accepted referral letters to the Department of Oral Medicine fell into the category of potential malignancy as defined by the referral guidelines. Of 241 referrals randomly selected from this group, eight (3.3\%) were diagnosed as malignant, 10 (4.1\%) dysplastic and $71(29.5 \%)$ as oral lichen

\begin{tabular}{|c|c|c|c|c|c|}
\hline $\begin{array}{l}\text { Patient } \\
\text { group }\end{array}$ & $\begin{array}{l}\text { No. of } \\
\text { patients }\end{array}$ & $\begin{array}{l}\text { Gender } \\
\text { male: } \\
\text { female }\end{array}$ & $\begin{array}{l}\text { Age range } \\
\text { Median } \\
\text { age }\end{array}$ & $\begin{array}{l}\text { Tobacco } \\
\text { Number } \\
(\%)\end{array}$ & $\begin{array}{l}\text { Alcohol } \\
\text { Number (\%) }\end{array}$ \\
\hline $\begin{array}{l}\text { No } \\
\text { dysplasia } \\
\text { evident }\end{array}$ & 223 & $105: 118$ & $\begin{array}{l}12-86 \\
56\end{array}$ & $\begin{array}{l}\text { CG } 145(65) \\
\text { SL } 4 \quad(1.8) \\
\text { BN } 7 \quad(3.2) \\
\text { NS } 67 \quad(30)\end{array}$ & $\begin{array}{l}59 \text { (27.8) greater than specified limit } \\
138 \text { (65.1) less than specified limit } \\
26(11.65) \text { No alcohol }\end{array}$ \\
\hline Dysplasia & 10 & 7: 3 & $\begin{array}{l}33-62 \\
48\end{array}$ & $\begin{array}{l}\text { CG } 4(40) \\
\text { SL } 0(0) \\
\text { BN } 0(0) \\
\text { NS } 6(60)\end{array}$ & $\begin{array}{l}2(20) \text { greater than specified limit } \\
2(20) \text { less than specified limit } \\
6(60) \text { no alcohol }\end{array}$ \\
\hline Malignancy & 8 & $5: 3$ & $\begin{array}{l}47-73 \\
63\end{array}$ & $\begin{array}{l}\text { CG } 5(62.5) \\
\text { SL } 0(0) \\
\text { BN } 1(12.5) \\
\text { NS } 2(25)\end{array}$ & $\begin{array}{l}4(50) \text { greater than specified limit } \\
3(37.5) \text { less than specified limit } \\
1(12.5) \text { No alcohol }\end{array}$ \\
\hline
\end{tabular}

CG-Cigarettes SL-Smokeless tobacco BN-Betel nut NS- Non smokers

SPECIFIED LIMIT OF ALCOHOL FOR WOMEN IS 14 UNITS/WEEK

SPECIFIED LIMIT OF ALCOHOL FOR MEN IS 21 UNITS/WEEK 


\begin{tabular}{|c|c|c|c|c|c|}
\hline $\begin{array}{l}\text { Age/ } \\
\text { gender }\end{array}$ & $\begin{array}{l}\text { Referring } \\
\text { diagnosis }\end{array}$ & Site of lesion & Final Diagnosis & $\begin{array}{l}\text { Tobacco } \\
\text { cigarettes/day }\end{array}$ & $\begin{array}{l}\text { Alcohol } \\
\text { units/week }\end{array}$ \\
\hline $39 / \mathrm{male}$ & $\begin{array}{l}\text { Persistent } \\
\text { ulceration }\end{array}$ & $\begin{array}{l}\text { left retromo- } \\
\text { lar area }\end{array}$ & Kaposi's sarcoma & $>20$ & $>21$ \\
\hline 50/male & $\begin{array}{l}\text { Persistent } \\
\text { ulceration }\end{array}$ & $\begin{array}{l}\text { left lateral } \\
\text { border of } \\
\text { tongue }\end{array}$ & $\begin{array}{l}\text { Squamous cell } \\
\text { carcinoma }\end{array}$ & $>20$ & $<21$ \\
\hline 40/male & $\begin{array}{l}\text { Cervical } \\
\text { lymphadenopathy }\end{array}$ & $\begin{array}{l}\text { Lump right } \\
\text { side of neck }\end{array}$ & $\begin{array}{l}\text { Squamous cell } \\
\text { carcinoma }\end{array}$ & nil & $<21$ \\
\hline $52 /$ male & $\begin{array}{l}\text { Persistent } \\
\text { ulceration }\end{array}$ & $\begin{array}{l}\text { Adjacent to } \\
\text { right upper } \\
\text { second molar } \\
\text { region }\end{array}$ & $\begin{array}{l}\text { Squamous cell } \\
\text { carcinoma }\end{array}$ & $<20$ & $<21$ \\
\hline 45/male & White patch & $\begin{array}{l}\text { Posterior } \\
\text { lateral border } \\
\text { of tongue }\end{array}$ & $\begin{array}{l}\text { Squamous cell } \\
\text { carcinoma }\end{array}$ & nil & $>21$ \\
\hline 72/female & White patch & $\begin{array}{l}\text { Ventral } \\
\text { surface of the } \\
\text { tongue }\end{array}$ & $\begin{array}{l}\text { Squamous cell } \\
\text { carcinoma }\end{array}$ & $>20$ & $>14$ \\
\hline $68 /$ female & $\begin{array}{l}\text { Persistent } \\
\text { ulceration }\end{array}$ & $\begin{array}{l}\text { Left buccal } \\
\text { mucosa }\end{array}$ & $\begin{array}{l}\text { Squamous cell } \\
\text { carcinoma }\end{array}$ & $\begin{array}{l}\text { Betel nut for } \\
30 \text { years }\end{array}$ & nil \\
\hline 49/female & White patch & $\begin{array}{l}\text { Ventral } \\
\text { surface of } \\
\text { tongue }\end{array}$ & $\begin{array}{l}\text { Squamous cell } \\
\text { carcinoma }\end{array}$ & $>20$ & $>14$ \\
\hline
\end{tabular}

planus - which may in itself have a 15\% malignant transformation rate..$^{8-11}$

A preliminary estimate of the proportion of urgent referrals with suspected oral cancer which were likely to be actually diagnosed with malignancy was suggested to be between 5-10:1 benign to malignant lesion ratio by the steering group responsible for the guidelines. The present study in fact describes a 30:1 ratio suggesting that for every 30 patients examined meeting referral guidelines, one malignancy will be diagnosed, with a $24: 1$ ratio for the detection of dysplastic lesions. The UK National guidelines would therefore appear to discriminate poorly between potentially malignant and other oral mucosal disease.

Although the referral guidelines detected the majority of malignant oral disease referred over 12 months, three patients with squamous cell carcinoma (27\% of total number of malignancies) and two severely dysplastic lesions (8.3\% of total number of dysplasias) were not identified from the description within the referral letter. In these instances the reason for referral was cited as orofacial pain with the primary care physician failing to detect the underlying cause. Despite pain being reported as a presenting feature of $60 \%$ of oral malignancies in the guideline it was not specifically included in the list of criteria for urgent umbrella term of cranial neuropathies. ${ }^{1}$ The proposed revision of the document should consider the inclusion of persistent/increasing oral mucosal pain as a criterion for urgent referral, especially from medical practitioners, the target group for this document.

An alarming lack of public awareness regarding oral cancer and associated risk factors has been demonstrated in the United Kingdom and this may potentially account for delays in presentation. ${ }^{2,12}$ Thereafter, waiting to receive a diagnosis and commence treatment not only results in patient anxiety but in addition, professional diagnostic delays of greater than one month are recognised to contribute to an increasingly poor prognosis in upper aerodigestive tract cancer. ${ }^{13}$ A delay in the diagnosis of oral malignancy may also be a cause

The drive to end waiting is central to the Cancer Plan, which introduces new targets to cut waiting times for referral to diagnosis and diagnosis to treatment. ${ }^{15}$ This, however, has not been universally accepted as being an evidence-based the two-week standard wait from referral to specialist oral medicine assessment we estimate that an average of a further 10 new patient episodes weekly are required. In a small, oversubscribed referral, unless inferred under the for litigation. ${ }^{14}$ strategy. ${ }^{16}$ In this unit alone, to achieve speciality with a limited number of clinicians in each unit, this would represent a significant increase in patient load. Patients referred with disease not meeting the criteria are therefore likely to experience longer waiting times for initial assessment - unless funding is secured to recruit clinicians and support staff to implement the guidelines. The resources of oral medicine units may be still further stretched by requests for 'urgent' assessments for benign conditions. Solutions to this dilemma need not necessarily involve expansion in the number of oral medicine clinicians but might also involve provision of medical undergraduate and postgraduate oral medicine teaching, encouraging practitioners to telephone departments to discuss patients who have concerning oral lesions and also sending digital photographs of the lesions with referral letters.

The referral letter remains the main means of communication between general practitioners and specialists in the process of patient referral. The importance of the quality of the oral medicine referral letter in obtaining a prompt and appropriate diagnosis has been previously reviewed.4.17 The essential

\begin{tabular}{|c|}
\hline $\begin{array}{l}\text { Fig. } 2 \text { Essential components of an oral } \\
\text { medicine referral letter }\end{array}$ \\
\hline $\begin{array}{l}\text { It is essential that the letter should be legible } \\
\text { whether typed or written and should include the } \\
\text { following to facilitate triaging: }\end{array}$ \\
\hline $\begin{array}{l}\text { 1. Referring clinician's details including name, } \\
\text { title, address and contact telephone numbers }\end{array}$ \\
\hline $\begin{array}{l}\text { 2. Patient's details including name, title, address } \\
\text { and contact telephone numbers }\end{array}$ \\
\hline $\begin{array}{l}\text { 3. Reason for referral, including description of } \\
\text { lesion or pain history if this is appropriate }\end{array}$ \\
\hline $\begin{array}{l}\text { 4. Perceived degree of urgency - if cancer is } \\
\text { suspected then the referral should be marked } \\
\text { urgent, mentioning the word cancer or 'treat } \\
\text { under the two week rule' }\end{array}$ \\
\hline $\begin{array}{l}\text { 5. What the referring clinician has said to the } \\
\text { patient about the lesion and the referral }\end{array}$ \\
\hline $\begin{array}{l}\text { 6. Relevant medical history including } \\
\text { drug history }\end{array}$ \\
\hline $\begin{array}{l}\text { 7. Relevant social history eg smoking or alcohol } \\
\text { history and any language needs }\end{array}$ \\
\hline $\begin{array}{l}\text { 8. The letter needs to be signed by the referring } \\
\text { clinician with his or her name } \\
\text { printed beneath }\end{array}$ \\
\hline $\begin{array}{l}\text { 9. If urgent the letter should be faxed and the } \\
\text { patient discussed by telephone with a } \\
\text { clinician directly. }\end{array}$ \\
\hline
\end{tabular}


components of an oral medicine referral letter are outlined in Fig. 2. To be counted under the two-week standard the referral letter must be marked urgent and also mention 'cancer' or 'treat under the twoweek standard'. ${ }^{1}$ Only 40\% of general medical practitioners' letters referring patients with potentially malignant oral disease, and none of the general dental practitioners, included this information. This discrepancy is not surprising since the referral guidelines target primary care medical practitioners. Although GMPs have previously been shown to have a poor knowledge of oral cancer in the United States ${ }^{18}$, in the United King$\mathrm{dom}^{2}$ they have been shown to be no less competent than general dental practitioners in the diagnosis and referral of malignancy despite limited undergraduate oral medicine teaching. The majority of referrals to oral medicine clinics arise from GDPs who remain unaware of the NHS directive - a fact highlighted when the document went out for consultation. ${ }^{1}$ It has been suggested that standard proforma letters for patients with probable malignant disease are likely to improve the standard of referral, ${ }^{4}$ however, opinion remains diverse regarding their use for urgent referrals. ${ }^{1}$ Model proformas are now available on the NHS website which may be customised to an individual unit's needs. ${ }^{19}$ Clearly it is essential that undergraduate and postgraduate dental and medical education should include the characteristics of a good referral letter in order to improve standards.

Smoking and alcohol consumption are associated with an increased risk of oral epithelial dysplasia. ${ }^{20-22}$ Surprisingly, of the group of 10 patients with oral epithelial dysplasia, a history of cigarette smoking or alcohol consumption was not associated with the presence of dysplasia. In seven patients with squamous cell carcinoma there was also no association with tobacco or alcohol consumption and the presence of the lesion. This result must clearly be interpreted with caution due to the small number of patients found to have potentially malignant or malignant oral disease and the unusually large number of cigarette smokers (65\%) and alcohol drinkers (93\%) in the comparison group of patients without malignant or oral epithelial dysplasia referred with possible malignant disease. Despite the non-significant associations in the present group of patients with potentially malignant or malignant disease, we would concur with the cancer referral guidelines, suggesting a greater degree of urgency of referral for patients with potentially malignant oral lesions who smoke and drink alcohol.

The introduction of guidelines for the referral of suspected cancer is an important step towards primary care practitioners identifying patients with oral malignancy and ensuring urgent specialist opinion. Over a 12 month period $85 \%$ of malignant and dysplastic lesions were identified in our unit by the national guidelines and this may be increased by introducing persistent pain to the referral criteria. The guidelines, however, failed to discriminate effectively between malignant and non-malignant disease - for every patient with confirmed oral epithelial dysplasia or malignancy, 25 to 30 patients fulfilling the referral criteria had to be evaluated. At this time it would seem appropriate to consider the workforce implications of the introduction of guidelines for the referral of patients with potentially malignant disease.

1. Referral guidelines for Suspected Cancer. (www.dh.gov.uk/PublicationsAndStatistics) Publications/PublicationsPolicyAndGuidance/ PublicationsPolicyAndGuidanceArticle/fs/ en?CONTENT_ID = 4008746\&tchk=jtslsg)

2. Scully C, Malamos D, Levers B G et al. Sources and patterns of referrals of oral cancer: role of general practitioners. Br Med J (Clin Res Ed) 1986; 293: 599-601.

3. Lamey P J, Samaranayake L P, Glass G W. Communication between a specialist dental hospital department and referring general dental practitioners: an attempt at clinical audit. Comm Dent Oral Epidemiol 1987; 15: 277-278.
4. Navarro C M, Onofre M A, Sposto M R. Referral letters in oral medicine: an approach for the general dental practitioner. Int J Oral Maxillofac Surg 2001; 30: 448-451.

5. Great Britain Department of Health. The new NHS modern - dependable. Her Majesty's Stationary Office, 1997. http://www.archive.official-documents.co.uk/document/doh/newnhs/newnhs.htm

6. The Organisation for Health Economic Co-operation and Development Health Data 2002 Table 18 Tobacco consumption, \% of population daily smokers. http://www.oecd.org/x/s/M00031000/ M00031402.xls

7. Williams R W, Hughes W, Felmingham S, Irvine G $H$. An audit of two week wait referrals for head and neck cancer. Ann R Coll Surg Engl (Suppl) 2002; 84: 304-306.

8. Eisen $\mathrm{D}$. The clinical features, malignant potential, and systemic associations of oral lichen planus: a study of 723 patients. J Am Acad Dermatol 2002; 46: 207-214.

9. Mignogna M D, Lo Muzio L, Lo Russo L et al. Clinical guidelines in early detection of oral squamous cell carcinoma arising in oral lichen planus: a 5-year experience. Oral Oncol 2001; 37: 262-267.

10. Lo Muzio L, Mignogna M D, Favia G et al. The possible association between oral lichen planus and oral squamous cell carcinoma: a clinical evaluation on 14 cases and a review of the literature. Oral Oncol 1998; 34: 239-246.

11. Markopoulos A K, Antoniades D, Papanayotou P, Trigonidis G. Malignant potential of oral lichen planus, a follow up study of 326 patients. Oral Oncol 1997; 33: 263-269.

12. Warnakulasuriya $K A$, Harris $C K$, Scarrott $D M$ et al An alarming lack of public awareness towards oral cancer. Br Dent J 1999; 187: 319-322.

13. Allison $P$, Locker $D$, Feine J S. The role of diagnostic delays in the prognosis of oral cancer: a review of the literature. Oral Oncol 1998; 34: 161-170.

14. Lydiatt D D. Cancer of the oral cavity and medical malpractice. Laryngoscope 2002; 112: 816-819.

15. NHS Cancer Plan September 2000 www.doh.gov. uk/cancer/pdfs/cancerplan.pdf).

16. Sikora K. New guidelines for urgent referral of patients with cancer are waste of energy. Br Med J 2000; 320: 59.

17. Zakrzewska J M. Referral letters - how to improve them. Br Dent J 1995; 178: 180-182.

18. Canto M T, Horowitz A M, Drury T F, Goodman H S. Maryland family physicians' knowledge, opinions and practices about oral cancer. Oral Onco/2002; 38: 416-424.

19. Department of Health Cancer Referral Proforma. www.dh.gov.uk/PolicyAndGuidance/HealthAndSocialCareTopics/Cancer/CancerPublications/fs/ en?CONTENT ID $=4066671$ \&tchk $=$ HLAuJC

20. Jaber M A, Porter S R, Gilthorpe M S et al. Risk factors for epithelial dysplasia - the role of smoking and alcohol. Oral Oncol 1999; 35: 151-156.

21. Jaber M A, Porter S R, Scully $C$ et al. The role of alcohol in non-smokers and tobacco in non -drinkers in the aetiology of oral epithelial dysplasia. Int J Cancer 1998; 77: 333-336.

22. Kulasegaram R, Downer M C, Jullien J A et al. Case-control study of oral dysplasia and risk habits among patients of a dental hospital. Eur J Cancer B Oral Cancer 1995; 31B: 227-231. 